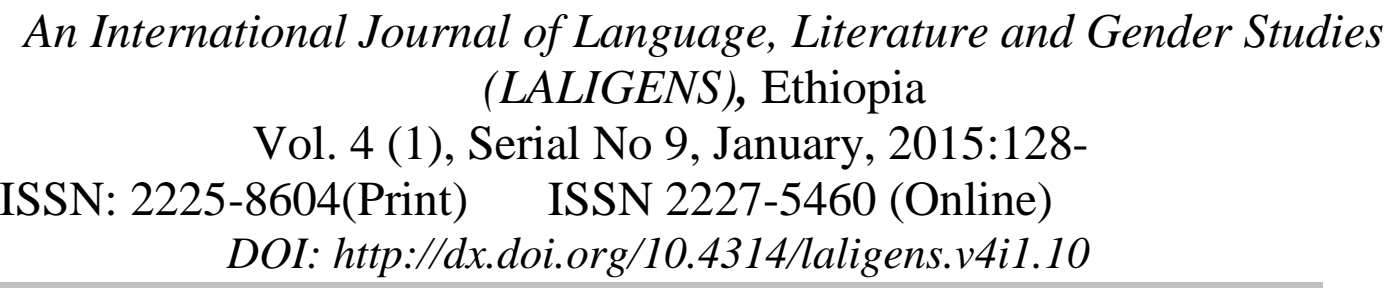

\title{
Radical Theatre in Contemporary Nigeria: A Review of the Contributions of Saint Gbilekaa
}

\author{
Asen, Marcellinus Aondohemba \\ Department of Theatre Arts, \\ Benue State University Makurdi \\ E-mail: asenmarcel@gmail.com
}

\begin{abstract}
The practice of radical theatre in the world generally has taken different dimensions in other to achieve different results by different scholars. In Nigeria and most countries of the world, radical theatre is gradually been metamorphosed into community theatre or theatre for development. This paper is a review of the contributions of one of the leading scholars on radical theatre in contemporary Nigeria-Saint Gbilekaa. Fundamentally, the paper reviews Saint Gbilekaa's book, Radical Theatre in Nigeria where so many issues on theory and criticism in the study of drama and theatre are raised. The paper concludes that, given the nature of our society, if the theatre is to be used as a weapon of collective struggle and human mobilization and liberation, it must encourage the people to protest and resist all oppressive structures in the society. If this is done, our leaders will be on their toes in delivering the desired quality of leadership needed by the people.
\end{abstract}

\section{Introduction}

According to Ode, "Books reflect the minds of the writers of such books. They express the hopes, fears, aspiration and dreams" (301). This is a truism because, it is only when you have read somebody's work that you can ascertain his ideological 
inclination hence all works of art project a particular identity. No wonder, Ngugi Wa Thiongo' asserts that,

A writer responds with total personality, to a social environment which changes all the time. Being a kind of a sensitive needle, he registers with varying degrees of accuracy and success, the conflicts and tensions in his changing society. Thus, the same writer will produce different types of work, sometimes contradictory in mood, sentiment, degree of optimism and even world view. For the writer himself lives in, and is shaped by history (47).

No doubt, the writer is shaped by history as he responds to the social, political, religious and economic issues in his society. This explains why some writers may seem to have one or more ideologies depending on the nature and issues in the society.

Radical theatre has established itself as one of the most famous popular presentational forms of theatre in Africa. Its popularity has undoubtedly assumed international dimension particularly because, it addresses the people's problems with a view of challenging them to woke up to the challenges of their time.

Founded under the precepts of Bertolt Brecht, he purports that, man and the social forces that drive him are alterable and that, with correct intellectual disposition and analysis, man can change his destiny. He believes that man is the product of his social environment and if his intellects are properly aroused to the social happenings around him, he is capable of deductive reasoning which would bring about change and development. This infact are the roots of radical theatre and it has enhanced political and social change in most societies of the world. In East Africa, the efforts of Ngugi Wa Thiongo' using his Kamiritu theatre facilitated the independence of the Kenyan people. In South and West Africa, it has created awareness on a variety of issues and even, gingered the people to embark on actions capable of bringing change in the society right from the colonial period to contemporary times.

\section{Review}

In the introductory part of the book, Radical Theatre in Nigeria by Saint Gbilekaa, he asserts that theatre has taken a definite ideological position in the ongoing class struggle worldwide. He presents two variants of radical theatre in Africa. One, is that practiced in the conventional western theatre as orchestrated by the likes of Ngugi Wa Thiongo' and Githiae Mugo, Ebrahim Hussein, Rugyendo, Femi Osofisan, Bode Sowande, Kola Omotoson, Ola Rotimi, etc. Two, is the community or popular theatre which is described as theatre of pedagogy, liberation and revolution with Marxist aesthetics as its yard stick. Countries like Botswana, Tanzania, Zambia, Kenya, Cameroon and Nigeria are all involved in popular theatre projects. In his discourse on 
the artistic and theatrical ferment in Nigeria, he asserts that the protests by Africans against the western cultural domination and ideological transfer facilitated towards the growth of black national and cultural consciousness which developed in to the new cultural renaissance giving way to folk opera and modern Nigerian theatre. $\mathrm{He}$ advances factors that have made Nigerian theatre to be unique in terms of style and content as: One, pre-colonial drama which is essentially traditional drama and two, colonial theatre which took the form of concerts. This gave birth to the literary drama. He concludes the introduction on the note that, this study is a continuum of the classic and ideological interpretation of drama, particularly the new radical theatre in Nigeria.

In chapter one titled, "The Development of Literary Drama in Nigeria", Saint Gbilekaa gives two broad classifications of theatre in Nigeria: the traditional and modern. The traditional is the product of man's attempt to redefine himself within his environment and to conquer tame nature. The traditional is subdivided in to sacred and secular while the modern tradition according to Clark includes the Yoruba folk opera and the literary drama which is reminiscent of the theatre in Europe and America. Yemi Ogunbiyi has updated Clark's classification by providing two broad classifications: the traditional and literary traditions of theatre. He has subdivided the traditional into three subdivisions: (i) Dramatic ritual (ii) the popular tradition, and (iii) Yoruba traveling theatre.

He has noted that, the origin and development of literary drama can be traced back to the church. He credits this to the Church Missionary Society, the Methodist Missionary society, the West Wesleyeans, the Baptists and the Catholics. He asserts that, 24th October, 1866 is seen as a significant date in the evolution of modern drama in Nigeria hence, an audience of merchants, churches, civil servants, students and artisans gathered to watch the first public concert of western music in Lagos. He asserts that, this kick started the emergence of other concerts and clubs like the Academy, and the Philharmonic society. He asserts that, besides the Academy and other dramatic clubs, the Missionary schools in Lagos contributed in promoting European culture and the arts. The Catholic Church is credited to have produced the greatest number of drama in colonial Nigerian concerts produced by schools and other dramatic clubs were influenced more by economic and social reasons than by intellectual and spiritual reasons. It was patronized by few elites who were few and saw it as a symbol of class identity.

The birth of Native drama is to a large extent credited to the role played by secessionist churches e.g. the Baptist Church, the United African Church etc who blended Yoruba indigenous material with European ones. They encouraged Mohammedans and traditional African religionists alike to attend and make meaning out their concerts as well as stimulating parents to send their children to school. These 
attempts at exploiting indigenous modes of expression and communication in the worship of God paved the way an authentic Nigerian drama. He applauds the Lagos Glu singers and Hurbert Ogunde's contribution to Nigeria Theatre. His early plays, The Gardern of Eden, and The Throne of God brought him in to lime light. His Worse than Crime and Strike and Hunger, Tiger's Empire, Towards Liberty_and Bread and Bullet clearly depict his commitment to liberation and Nigerian independence.

On the Onitsha market literature, he attributes it to historical and economic factors. Though the novelettes, playlets and stories written by members of an emerging literate class of traders, artisans and the working persons for mass literate audience lacked literary merit and artistic fit, they provided a cue for the theatre historian and critic to visualize the emerging forms of contemporary Nigerian Theatre.

On the literary tradition, he notes that, Ene Henhaw was the first Nigerian playwright to write in English. His plays include: This is Our Chance, (1956) A Man of Character, Children of the Goddess, (1964) Dinner for Promotion (1965) Magic in the Blood, Jewels of the shrine etc. nevertheless; the birth of a more serious drama in English in Nigeria was pioneered by university college Ibadan. This raised a greater level of awareness with arts theatre production group, the University College Ibadan Dramatic Society; Hoi Phrontistai etc really propelled the course of literary drama in Nigeria. The return of Soyinka in 1960 radiated dramatic activities in post independence Nigeria. The euphoria of independence stimulated a deep sense of cultural awareness. Soyinka's "1960 Marks", A Dance of the Forest, contributed to the celebration of independence.

Saint Gbilekaa concludes the chapter that, all notable Nigerian Playwrights in English are products of the university experiment e.g. the likes of Soyinka, Clark, Rotimi, Wale Ogunyemi, Zulu Sofola, Femi Osofisan, Bode Sowande and Iyorwuese Hagher.

In chapter two titled, "Marxist Aesthetic Debate and the Impact on Drama in Nigeria", Gbilekaa presents the formalist and radical schools of literary appreciation. The formalist is anchored on the precepts of Aristotle and Hegel while the latter on that of Marx and Engles. He notes that, these schools are based on ideological persuasion on the relationship between art and society as well as art and politics. In discussing Aristotelian and Hegelian aesthetic conduct, he asserts that, tragedy occurs when man in pursuit of certain objectives like justice, happiness, and honour fails to achieve them. He reiterates that, tragedy presents to the audience a man undergoing a radical reversal of fortune. He presents Aristotle's view on tragedy that it must attract pity which arises out of underserved misfortune and fear through empathy. Hegel on the other hand, sees tragedy as the greatest art because it redefines the forces of collisions which the world's historical spirit must go through in its self- actualization in history. In this way, the protagonist and antagonist unleash forces that collide and 
reveal societal contradictions which must be annihilated. Marx and Engels argued that tragedy based on historical events dramatizes the conflict of men and forces based on socio-historical roots of tragic issues. The conflict becomes more in revolutionary historical tragedy. Saint Gbilekaa cites the case of Lasalle's Franzvon Sickingen which provides insight on the character of revolutionary tragedy.

On the other hand, he discusses Aristotle's Poetics as an instrument of intimidation hence it evokes a cathartic effect. Theatre he notes is a double edged sword and can be to liberate and intimidate which Aristotle has done. On aesthetic ideas of Marx and Engels on art and literature, he notes are an integral of a whole vision of the world. They try to redefine the relationship between art and ideology, the nature of artistic creation under capitalism, the class origin and the class character of life, and the uneven development of art and society. He reiterates that, Lenin made significant contributions in the development of artistic vision of Marx and Engeles. In his theory of reflection, he argued that, literature should be used to enhance material benefits to groups or individual but should help fight the cause of the proletariat. Furthermore, he highlights Bertolt Brecht's contribution to the development of Marxist Poetics. Brecht attacks the ideological stance of bourgeois theatre on the grounds that it coaxed the audience in to empathizing with the tragic hero. He opposes Aristotelian theatre and its affiliates because; it provides escapist entertainment for men trapped in that assumption. According to him, the popular artist who wants to influence his society must turn away from down-town sages to the neighbourhood where he can meet people who are interested in changing society. To him, the theatrical spectacle is the beginning of action to which the equilibrium is attained through societal transformation and not through purgation of the individual.

Saint Gbilekaa presents the literary battle between Brecht and Lukacs in 1930s on expressionism and realism. Brecht holding on the works of formalist writers while Lukacs, pure Marxist aesthetics ideas. To Brecht, to master reality entails, “... using every means, old and new, tried and untried, derived from art and elsewhere, to render reality to men in a form they can master" (82). This implies that, reality is not static but changes. As such, repressing it requires a dynamic approach. Lukacs on the other hand, holds that, literary productions dismantle capitalist contradictions between truth and illusion as well as reality and the abstract. In the same line with Brecht, Lucien Goldmann asserts contends that, literary works project world visions which are a reflection of the society. He opines that, social life determines literary creation and this is a fundamental component of dialectical materialism which gives prominence to economic factor and class relations.

Saint Gbilekaa holds that, these major theories and crisis in the world's literary scene has affected and influenced African literature consciously or unconsciously. $\mathrm{He}$ asserts that, the view of literature as a conscientization medium is gradually gaining 
grounds in Africa and most third world countries. He adds that, the commitment of African writers has to be holistic and not just mere protest as it embraces both politics and social or economic view of the society.

On Negritude movement he asserts that it has two modes; the revolutionary and mystique and should not be viewed from monolithic angel just like some Eurocentric scholars do. Commenting on art for art's sake, he presents the various stances of writers ranging from Dan, S. Izevbaye, Nagenda John to Onege. One fact remains clear, the advocates of art for art's sake school have not grounded their criticism on any concrete theory of opposition to the prevalent philistinism of new-colonialism. Besides, the history of Africa is unique and plays a significant role in the art.

On critical realism he asserts that, these categories of writers are those who call for committed literature that can confront contemporary reality in a critical way. They eschew ideology but call for social vision of the society. On the other hand, he contends that socialist realism form ideas and allow them to develop in the process of work and time. A socialist realist writer is one that anticipates the future. They include: Ngugi Wa Thiongo, Femi Osofisan, Sowande, Omotose, etc.

In chapter three, Saint Gbilekaa presents the radicalism in Femi Osofisan's selected plays which amounts to a combination of history, myth and theatricalism. He sees Osofisan's drama as a medium of instruction which creates a unique theatre that seeks to arouse the audience critical awareness of the prevailing social decadence and thus, move them in to taking appropriate actions that will improve their standard of wellbeing. His plays ranging from: The chattering and the Song, Once Upon Four Robbers, Morountodun, or Another Raft etc have attacked all forms of corruption, oppression, injustice and tyranny. The theme of exploitation and liberation cuts across all his plays. He uses myths, legends and history to explain the social happenings in the society as can be seen in Morountodun, Once Upon Four robbers, The Chattering and the Song etc. Osofisan is viewed as a revolutionary writer and this revolution can best be achieved through collective action. He is credited to be Nigeria's best radical dramatist.

In chapter four, Saint Gbilekaa presents the spiritual and revolutionary romanticism versus pure dialectics in the drama of Bode Sowande and Kole Omotoso where he asserts that, though both Sowande and Omotoso explain the suffering of the masses, there is a fine line between them. While Sowande's vision is not affected by ethical considerations in the spiritual and metaphysical realm, Omotoso feels there should be a marriage between egalitarian and spiritual realm. This stems from the fact that our problems have been multiplied by the lack of spiritual considerations. Saint Gbilekaa has analyzed two of Sowande's plays: The Night Before and Fare Well to Babylon. These plays have a link with each other especially because they dramatize the 
difference between revolutionary romanticism and revolutionary praxis. Finally, they present the need for revolutionary struggle and what the people are expected to do in the mist of problems.

On the other hand, Omotoso's plays call for the establishment of an egalitarian society through Marxist dialectical method. This implies destroying the entire capitalist superstructure and replacing it with a socialist one. His plays essentially aim at redefining the quality of life of the Nigerian populace. His plays, The Curse and Shadows in the Horizon call for reassessment of the past in order to chart the revolutionary song. The pays project fundamentally, the aims and aspiration of the proletariat class. His vision of social change stems from historical and materialist approach to socio-political matters which are highly dialectical.

Chapter five captures the romance with the left: Ola Rotimi new artistic vision where Saint Gbilekaa asserts that Ola Rotimi is one of Nigerian's leading playwrights who is an accomplished theatre director and consummate aesthetic and has gain prominence on the Nigeria theatre stage particularly after the Nigerian civil war. His plays, The Gods are not to Blame (1971), Our Husband Has Gone Mad Again (1977), Kurunmi (1971), Ovonramwen Nogbaisi (1974) Holding Talks (1983), If,..._(1983), Hopes of the Living Dead have no doubt played a significant role in the literary history of Nigerian dramatic literature.

His earlier plays, The Gods are Not to Blame, Our Husband has Gone Made Again, Kurunmi, Ovonramwen Nogbaisi placed him on the same ideological class with Soyinka and Clark-Bekederemo and Ogunyemi. This is because, in dramatizing history, he records it to suit technical and artistic aspects as well as his ideological spectrum. In, Kurunmi, he identified himself with the ruling class. This is also applicable to The Gods are Not to Blame and Ovornramwen Nogbaisi._However, his If,... and Hopes of the Living Dead_elevate him to the same ideological class with Osofisan, Sowande, Omotoso and Tunde Fatunde. This is because; he has applied the cannons of Marxist historical determinism in examining the practice of politics in Nigeria. With if... and Hopes of the Living Dead, he has displayed enough signs of radical growth which has placed him on firm ideological grounds which contradicts with his earlier ideology. He has shown in these plays that, drama is an effective revolutionary weapon which can be used to awaken the consciousness of "the dead" towards radical perspectives. Saint Gbilekaa however observes that, Rotimi's romance with the left has concretized into socialist ideological vision as seen in his recent plays. His change cannot be completely guaranteed hence he is still in the process of growth.

In chapter six titled, "A New Theatre Aesthetics and the Radicals", Saint Gbilekaa admits that there has been a general research for a dramatic technique that can best 
express the playwright's radical political vision in other to conform to total theatre. $\mathrm{He}$ has therefore discussed the theatricalism of Osofisan, Sowande, Omotoso and Rotimi's new theatre language. He asserts that Osofisan's theatrical style is anchored on the African oral narrative tradition. This includes incantation, poetry, songs, music, dance, chants and spectacle. He draws his raw material from myths and history.

In the same vein, Sowande to some extent thrives on oral tradition to heighten his audience understanding of his plays as well as shed light on this socio-cultural message. He however, uses more conventional aesthetic devices such as flash backs, playlets, interpololated songs, pantomimes and direct addresses. These can be seen in his The Night Before and Fare Well to Babylon as these plays lack remarkable abbreviation of language, mascaraed, play-with-in- a play etc but rely heavily on verbal dialogue to communicate.

On the other hand, Omotoso's theatricalism is an adoption of the representational and expressionist technique of abbreviating the verbal content of his plays with non verbal elements. He uses elaborate sets and numerous props as can be seen in his The Curse and Shadows in the Horizon. Incidentally, this is a situation both Osofisan and Sowande have avoided.

On Rotimi's new theatre language, Saint Gbilekaa asserts that, his style is a borrowing from the African (Yoruba in particular) theatrical atmosphere. However, what is evident from this style is a mixture of the African folktale narrator in taking liberties with the already familiar story in the course of narration and interpretation as well as his acting technique. This technique which accommodates different actions taking place on the stage at the same time is however common in some African performances. He makes use of traditional creative abilities such as dance, mime, songs, and multi-lingual experiments as this can be seen to be successfully handled in If ... and Hopes of the Living Dead.

All these playwrights Saint Gbilekaa asserts have used conventional concepts of stage craft and the form of their theatre is African. Their usage of formalist structures conforms to Bertolt Brecht's use of Aristotelian elements in his epic theatre.

In chapter seven which is the last titled: "Towards a Methodology and convention to a more Relevant Radical Theatre in Nigeria", Saint Gbilekaa asserts that, radical theatre started in Nigeria as a theatre of protest and dissatisfaction with European cultural invasion and hegemony. It has undergone many stages over the years. First, in the 1940s and 50s, it was used for propaganda and to comment on politics during the Nationalist struggle for independence. Ogunde's agitation and propaganda cannot be over emphasized. His theatre succeeded in raising the consciousness of the people to the need for self government. However, his art at independence was put to the service 
of the ruling class. Besides, it was a bourgeois theatre as the content of the drama and the ideology was that of the ruling class in spite of the traditional fusion and foreign style as this can be seen in the Yoruba operatic theatre, the Onitsha Market drama and the drama of Ene Henshaw.

In the 60s Soyinka's pays; Before the Black Out and Kongi's Harvest and J.P. ClarkBekederemo's The Raft Mounted Overt attack on issues as well as those who abused political power. They thought they could correct the ruling class attitude but this did not yield good results.

The mid 70s provided what is truly known as radical theatre in Nigeria taking a cue from Brecht, Boal and Freire. The likes of Osofisan, Sowande and Kola Omotoso employed Marxist -Leninist theory of Historical and dialectical materialism in the analysis of socio-economic problems and proffer solutions. Saint Gbilekaa presents an eight point methodological approach that popular theatre adopts in raising consciousness among the masses. These include: Meeting with community leaders to set the stage and scene for permission, research and data collection, data analysis, casting and rehearsals, criticism of rehearsals, performance, evaluation and follow up.

\section{Conclusion}

I wish to agree with Saint Gbilekaa that, if the theatre is to be used consciously as a weapon of collective struggle and as an instrument of demolishing the squalid institutions that exploit and degrade humanity, it must involve the people. It must encourage them to protest, to resist and to challenge all oppressive masses. By the time this move is made, political leaders and those in positions of authority will treat the affairs of the state with decorum and improve the quality of life of the people knowing the consequences of their reversed action.

\section{Works Cited}

Brecht, Bertolt In, Aesthetic and Politics: Debates between Ernst Bloch, George Lukacs, Bretolt Brecht, Walter Benjamin, Theodore Adornno, London: New left Books, 1977.

Ngugi Wa Thiongo, Home Coming. London: Heinemann Educational Books Ltd, Bedford Square, 1982.

Ode, R. "The Theme of Retirement as Explored in Iyowuese Hagher's the Professor and the Cathedral". In, Journal of Arts and Seminar Series. Makurdi, Vol.1, 2002.

Saint Gbilekaa, Radical Theatre in Nigeria. Ibadan: Caltop Publication, 1997. 